\title{
Wielka awantura, czy o ,monidło"? Jana Himilsbacha semiotyka groteski i dyskurs humanistyczny
}

Jerzy Winiarski 
nAP7S Seria XIV 2008

Jerzy Winiarski

\section{Wielka awantura, czy o „monidło”? Jana Himilsbacha semiotyka groteski i dyskurs humanistyczny}

$\mathrm{J}$

an Himilsbach (1931-1988) wydał swoją pierwszą książkę - zbiór opowiadań Monidto - w 1967 roku. Trzeba koniecznie dodać, że poprzedziło ten akt 16 lat prób i prac pisarskich autora, jeśli zważyć debiutancki wiersz - Będę poeta - opublikowany w 1951 roku ${ }^{1}$. Trzeba o tym pomyśleć, kiedy czyta się dzisiaj, po przeszło czterdziestu latach, ówczesne recenzje Monidła, w których krytycy bardzo niepewnie próbowali określić zapowiadający się właśnie charakter pisarski autora. A to z powodu, po pierwsze, jego iście lumpenproletariackiego pochodzenia i braku formalnego wykształcenia inteligenckiego, następnie zaś z powodu przeczącego tym uwarunkowaniom i determinizmom poziomu sprawności warsztatowej początkującego prozaika oraz literackiej atrakcyjności jego opowiadań.

Zawodowi krytycy jakby zaniemówili, nie bardzo wiedząc, jakie stanowisko zająć na przyszłość. Wahali się, czy w ogóle można się odważyć na otwartą pochwałę autora tej niecodziennej dawki hiperrealizmu, opatrzonej w dodatku tyleż intrygującym, co niezrozumiałym tytułem, do dnia dzisiejszego zresztą kłopotliwego, bo wywodzącego się z bardzo specyficznych, od dawna już zapomnianych rejonów kultury „oddolnej”, popularnej, ba! dosłownie jarmarcznej, niskiej, kiczowatej, szerzej nieznanej, peryferyjnej.

Jacek Kajtoch bardzo ekspresywnie i wartościująco zatytułował swoją recenzję książki Himilsbacha - Pisarz dnia siódmego ${ }^{2}$. Zauważył, że autor jest „ewenementem jako osobowość" i stwierdził, że:

\footnotetext{
1 Zob. hasło: Himilsbach Jan 1931-1988, Prozaik, scenarzysta, aktor filmoury, w: Wspótcześni polscy pisarze i badacze literatury, Słownik biobibliograficzny, opr. zespół pod red. J. Czachowskiej i A. Szałagan, t. 3, Warszawa 1994, s. 255-256.

2 Zob. J. Kajtoch, Pisarz dnia siódmego, „Twórczośc” 1968 nr 4, s. 97.
} 
przede wszystkim stanowi zjawisko natury socjologicznej; utalentowany samouk, pisarz niedzielny, autor pochodzący ze środowiska pracy fizycznej i wcale $z$ nim nie zrywający więzów, kamieniarz, który [...] latem pracuje, a zimą układa opowiadania ${ }^{3}$.

Antycypacje takiej sytuacji recenzent dostrzegł w międzywojniu, w przypadkach Zbigniewa Uniłowskiego, Jana Brzozy i Henryka Worcella, którzy wywodzili się z proletariatu i nie mieli literackiego przygotowania. Dzisiaj można by wskazać nie tyle osobowe, ile raczej programowe wzorce twórczości Himilsbacha, grupę „Przedmieścia”. A to wiele zmienia w spojrzeniu już nie na debiut, ale w ogóle na całokształt dorobku prozatorskiego autora Monidła. Konsekwentny w socjologicznym spojrzeniu na casus Himilsbacha, recenzent położył nacisk na materialno-społeczne dominanty jego prozy i wyłowił w omawianym zbiorze opowiadań dwa główne motywy organizujące fabułę i tworzące rzeczywistość przedstawioną: motyw okupacyjny oraz życie współczesnych proletariuszy w małomiasteczkowym środowisku. Himilsbach pozostal dla Kajtocha - dodajmy, w recenzji opublikowanej w rok po debiucie i towarzyszących mu wypowiedziach krytycznych — wyłącznie

bystrym obserwatorem społeczności, przede wszystkim zaś wzorów postępowania, form współżycia, pojęć moralnych ${ }^{4}$.

Krytyk podal przy tym dostateczne argumenty - tytułowe Monidło oraz Ślub wagonii. Nie wdał się jednak w żadne zabiegi analityczne czy też interpretacyjne, nie podał też żadnych tropów swojego rozumienia szczegółowych znamion estetyki tych utworów. Zakończył zaś swój wywód konsekwentnie, wskazując na umiejętność Himilsbacha pisania bez „mitologizacji, bez literackiej sztukaterii”. Tym samym wpisał autora Monidła w pejzaż kształtującej się dopiero co „literatury faktu” i atmosferę „małego realizmu", w tym wypadku proletariackiego, tak czy inaczej — przyziemnego światka peerelowskiej rzeczywistości.

Zgoła inaczej, bez chłodnego, sformalizowanego dystansu, pisał rok wcześniej o tym debiucie recenzent warszawskiej „Kultury” Janusz Glowacki, który pozytywnie i śmiało ocenil debiutancką książkę Himilsbacha. Po niejakim zastanowieniu zaliczył ją do „kategorii literatury prawdziwej, bez żadnych zastrzeżeń" go języka opowiadań, który, co słusznie zauważyl, świadczył o dużej wrażliwości autora. A jak wiadomo, bez wrażliwości, czyli bez zdolności dojmującego przeżywania świata, $\mathrm{w}$ tym także jego imponderabiliów, nie ma artysty. $Z$ całej zawartości książki recenzent

${ }^{3}$ Ibidem, s. 98.

${ }^{4}$ Ibidem, s. 99.

${ }^{5}$ Ibidem.

${ }^{6}$ J. Głowacki, Himilsbach, „Kultura” 1967, nr 40, s. 9. 
wybrał otwierające ją Chrzciny jako najlepsze opowiadanie. Dokonał przy tym ważnego odkrycia. Potwierdził mianowicie swoistą polisemię (wielość znaczeń) tych kompozycji. Zaś bez symbolizacji języka tekst nie mógłby przecież zaistnieć w kulturze jako zjawisko literackie. Co ważne, recenzent zwrócił też uwagę czytelników na szczególną kreację narratora w opowiadaniu Himilsbacha, którym jest mały chłopiec. Podnosiło to od razu temperaturę uczuciową i zaostrzało problematykę prozy tego autora, otwierającej wizję egzystencjalną i społeczną przedstawionej rzeczywistości.

Andrzej Makowiecki zaś powitał debiutancki zbiór 16 opowiadań Himilsbacha dylematem poznawczym i aksjologicznym: Spontaniczność czy "literatura" . Ten badacz niezwykle przenikliwie i inspirująco dla czytelników określił charakter twórczy autora i dał właściwą miarę realnego pejzażu jego utworów, wdając się w spór ze zgłaszanymi w potocznych opiniach wątpliwościami:

Ale przecież ten pan z jarmarcznej fotografii przynależy bardziej do świata kulturą skażonego niż do rzeczywistości pełnej witalnej spontaniczności. Przecież ten pan ów świat aż za bardzo literacko przetworzył. Himilsbach — podejrzewam — i w życiu prywatnym porusza się częściej wśród zwolenników Wirginii Woolf niż kamieniarzy. [...] Toteż prezentowana rzeczywistość Himilsbacha nie fascynuje — jak Marka Nowakowskiego i Marków wcześniejszych — je s t je d y n i e [wyróżn. - J. W.] terenem obserwacji, na którym autor najlepiej się czuje ${ }^{8}$.

Krytyk podkreślił kreacyjny charakter tej prozy i jej wartość literacką, obecność świadomej obróbki pisarskiej. Himilsbach nie jest „pisarzem niedzielnym” — zawyrokował. Odkrywczo pokazał przy tym istotę estetyki opowiadań Himilsbacha:

Autentyk środowiskowy, rzeczowa obserwacja w niepostrzeżony sposób przeradza się w literacką groteskę — makabryczną jak realia śmierci Felka z Florki, mrożkopodobną — w finale Monidła czy W imieniu prawa9.

Wnioski dotyczące pisarza po tak specjalistycznej wiwisekcji mogły być tylko pozytywne, a ocena wysoka. Warto je zapamiętać. W konkluzji Andrzej Makowiecki napisał:

Elementarne rozróżnienie między narratorem i autorem, między kreowanym światem z jego systemem wartości a uogólniającym dystansem pisarskim każe w opowiadaniach Himilsbacha widzieć bardzo sprawną warsztatowo i o wysokim poziomie literackim prozę ${ }^{10}$.

\footnotetext{
7 A. Makowiecki, Spontanicznośc czy ,literatura”, ,Tygodnik Kulturalny” 1967, nr 51, s. 4.

${ }^{8}$ Ibidem.

${ }^{9}$ Ibidem.

${ }^{10}$ Ibidem.
} 
Dwadzieścia lat później Leszek Bugajski, komentując w swej krakowskiej książce "gawędy Himilsbacha”, wyraźnie pozostał pod wpływem akademickiego autorytetu Jacka Kajtocha i odmówił temu pisarstwu jakichś istotniejszych wartości ${ }^{11}$. Zdziwienie krytyka wzbudzila rosnąca popularność pisarza. Już na wstępie swego szkicu autor ogłosił tezę, od której nie odstąpił do końca swego wystąpienia:

Fenomen powodzenia prozy Himilsbacha zasługuje na uwagę, jeśli zauważyć, że jej wartość artystyczna nie jest wysoka i że nie jest to proza tworzona ze świadomością wszystkich celów oraz środków artystycznych czy intelektualnych. Jest to przede wszystkim swobodna, spontaniczna opowieść narratora o własnych życiowych perypetiach, relacja zasłyszanych gdzieś opowiastek ${ }^{12}$.

W celu bliższego poznania właściwości pisarstwa Jana Himilsbacha przyjmujemy założenie, że tytułowe Monidło z debiutanckiego zbioru opowiadań można uznać za estetyczny model stylu tego autora (w szerszym, kulturoznawczym sensie), poetyki immanentnej oraz językowego obrazu świata jego utworów. $Z$ tego też powodu znaczenie opowiadania Monidto dla wyjaśnienia fenomenu artystycznego Jana Himilsbacha jest wyjątkowe, a interpretacja tego tekstu, o czym jesteśmy przekonani, jest kluczowa dla poznania świadomości literackiej autora, który wedle niektórych krytyków był „bez świadomości"'13. Interpretacja Monidła winna też odpowiedzieć na podstawową kwestię: czy autor patrzy na świat z „krótkiej ogniskowej”, czy jest obserwatorem wyłącznie marginalnego światka, czy przeciwnie, zmierza do szerszej perspektywy oglądu rzeczywistości człowieka.

Pomimo tego, że pisarz byl peryfrastycznie określany jako „autor Monidła”, ono samo ani w jednym zdaniu nie stało się przedmiotem jakiejś refleksji. Zdaje się, że opowiadanie to mogłoby odsłonić pewną zasadę estetyki i postawy ideowej tego pisarza. Na początku popatrzmy na ekspresję utworu, na jego zawartość fabularną, która steruje odbiorem. Spójrzmy na c zy tan ie an egdotyczne tej-patrząc z perspektywy początków dwudziestowiecznej konwencji literackiej — „tragifarsy niekołtuńskiej”, na komediowe postaci i ich interakcje, na satyrę społeczną z życia „nizin” oraz na „czarny humor” opowiadania, odbierający mu jakąkolwiek cechę wypowiedzi „serio”, powagę sytuacji związanej z uwikłanymi w niej ludźmi.

Anegdotyczne czytanie Monidta prowadzi do swoistej entropii - eksplozywnego rozrostu - ekspresji opowiadacza i zatrzymuje jego obraz fabularny

\footnotetext{
${ }^{11}$ Zob. L. Bugajski, Gauędy Himilsbacha, w: idem, W gąszczu znaczeń, Kraków 1988, s. 123-128.

${ }^{12}$ Ibidem, s. 123.

${ }^{13}$ Andrzej Makowiecki widzial w Himilsbachu kreatora, dla Leszka Bugajskiego (op. cit., s. 128) autor Monidła "ledwie stara się dorównać najbardziej konwencjonalnej prozie narracyjnej”.
} 
w ludycznych ramach. Patrząc z perspektywy odbioru ${ }^{14}$, anegdota nie wyodrębnia podmiotowości wirtualnego czytelnika, to jest nie indywidualizuje go, a niejako narzuca standardowy kontur rysunku masowego odbiorcy, „widza” przyziemnego wydarzenia, które wywołuje zarazem śmiech i zgrozę.

Monidto jako a n e gd ot a obyczajow a jest rodzajem satyrycznego opowiadania - wspomnieniem narratora z dzieciństwa - o opłakanych skutkach kupna artystycznej tandety: malowanych, retuszowanych i rekomponowanych zdjęć ściennych, ślubnych oraz portretów, zwanych przez rzemieślniczych wytwórców właśnie „monidłami”. Zamówił je we własnym mieszkaniu za namową sprytnego akwizytora małomiasteczkowy robotnik, na co dzień klepiący biedę. Podochocony wódką i zaprezentowaną wizualizacją końcowego efektu dał zaliczkę w postaci sporej części dopiero co otrzymanej wypłaty. Żona nie mogła temu zapobiec, bo wyszła w ten targowy dzień, chcąc tanio zakupić żywność dla swej rodziny z czworgiem dzieci. Jej powrót jeszcze przed odejściem domokrążcy dał początek rodzinnej sprzeczce i rychło awanturze, która zakończyła się około północy ciężkim pobiciem kobiety przez rozzłoszczonego męża za jej wymówki oraz przeciwdziałanie tej transakcji. Pozwoliło ono nawet - jeśli powrócimy do początku zatargu o „monidło” — odzyskać częściowo wpłaconą zaliczkę, ale dotknęło zarazem poczucia „honoru” zupełnie już pijanego męża. To właśnie akwizytor podszepnął mu w akcie zemsty cielesne ukaranie krnąbrnej żony, co też małżonek gorliwie uczynil.

Ostatecznie z „monidła” wyszły przysłowiowe „nici”, gdyż malowane zdjęcia okazały się koszmarnie wykonane i groteskowo zniekształcone. Zapewne także i z rozwodu, o którego przeprowadzenie wniosła w finale wydarzeń poszkodowaną żona, również — na szczęście - nic nie wyszło. Należy mniemać, że wspólny los, rozczarowanie i otrzeźwienie po fakcie, pogodziły wkrótce tych dwoje „pospolitaków”, jeśli określić ich wedle miary codziennej biedy i minimalnych potrzeb życiowych, które ze sobą dzielili.

Monidto czytane w porządku fabularnym stanowi realistyczny obrazek z życia „niższych sfer”, behawiorystyczny rysunek pijaka, a zarazem męża i ojca, oraz udręk jego rodziny i towarzyszącego jej niedostatku. Tematem opowiadania, odwołując się do planu narracyjnego, byłaby przyziemność życia, zredukowani przez nią w swej zgrzebnej egzystencji ludzie oraz skutki podstępu handlowego komiwojażera, żerującego na takich jak oni, przedstawiciela oszukańczej spółki „artystów”, wykorzystującej naiwność odbiorców swoich produktów. W sumie temat opowiadania byłby anegdotyczno-satyryczny, a od strony językowo-stylistycznej realistyczny, swoiście reportażowy i prawdziwy pod względem psychologicznym. W takim też kierunku poszła adaptacja telewizyjna Antoniego Krauzego (1969). W tym stanie rzeczy utwór nadawałby

${ }^{14}$ Zob. ogólną problematykę „poetyki odbioru”, zwłaszcza rozdział Wirtualny odbiorca $w$ strukturze utworu poetyckiego, w: M. Głowiński, Style odbioru, Szkice o komunikacji literackiej, Kraków 1977, s. 60-62. 
się w swej najwyższej wymowie do wykorzystania przez propagandę antyalkoholową i do ostrzegania prowincjuszy przed szalbierzami z miasta.

Rysuje się jednak możliwość innego sposobu odczytania. Kwestie stylu odbioru oraz wirtualnego odbiorcy dzieła stawiają przed badaczem problem bliższego rozpoznania konwencji utworu literackiego. Nasza hermeneutyka Monidta uzupełnijmy podaną na wstępie hipotezę interpretacyjną - zmierza do podkreślenia nie tyle realizmu estetyki opowiadania, ile jej pa r a b ol i c z n ości. Michał Głowiński tak oto pisał o tym zadaniu poznawczym:

Rozpoznanie konwencji jest warunkiem zrozumienia, czy też — właściwej recepcji utworu. Dzieło, realizujące zasady danej konwencji, projektuje i narzuca odbiorcy pewnego typu zachowania w stosunku do siebie, które umożliwiają zrozumienie utworu. Chodzi nie tylko o umiejętność odczytania sensów pojęć użytych w tekście, ale o uchwy cenie reguł ich wiązania [wyróżn. - J. W.] ${ }^{15}$.

Z tą właśnie świadomością metodologiczną spójrzmy na realistyczne detale Monidta, na strukturę głęboką znaków jego kodu symbolicznego, motywującą fabułę i charakter świata przedstawionego, zwłaszcza zaś na sposób konceptualizacji wydarzeń dorosłego już ich uczestnika, a zarazem narratora. Postawmy też, już na wstępie naszego nie anegdotycznego, lecz semantycznego - czytania Monidła problem tematu opowiadania, który w tej perspektywie będzie konkretyzowany inaczej niż uprzednio. Przyjmujemy za Andrzejem Stoffem, że

temat jest wynikiem poznania utworu[wyróżn. - J.W.], skutkiem poszukiwania uogólnionej formuły dla jego treści ${ }^{16}$.

A za toruńskim teoretykiem literatury dodajmy jeszcze i to:

Funkcją tematu jest więc wskazywanie tego zakresu rzeczywistości, którego utwór dotyczy, to jest: który przedstawia, problematyzuje i proponuje w określony sposób zrozumieć ${ }^{17}$.

Czytanie zatem nie anegdotyczne, lecz se mantyczne może przynieść zasadniczą zmianę w pojmowaniu zawartej w utworze sceny fabularnej i jej wymowy. Może

\footnotetext{
${ }^{15}$ Ibidem, s. 75 i nast.

16 „Temat jest jednym z tych terminów literackich, które upoddane bliższemu rozpatrzeniu po prostu obezwładniają wielością i rozmaitością swoich użyć»". Tak oto, od sądu Janusza Sławińskiego rozpoczął swoje studium Andrzej Stoff (idem, Temat utworu literackiego, w: $Z$ teorii dzieła literackiego, red. A. Stoff, M. Cyzman, Toruń 2003, s. 121).

${ }^{17}$ Ibidem, s. 127.
} 
także rzucić nowe oświetlenie na postawę pisarza i jego relacje $z$ odbiorcą. Kluczem otwierającym „przestrzeń głęboką" Monidła jest czas. W porządku fabularnym ma on charakter realny i obejmuje wydarzenia „rzeczywiste” (fikcja literacka), rozwijające się w opowiadaniu progresywnie, linearnie i konstruujące jego akcję, od momentu jej zawiązania do zakończenia. Można by go nazwać c zasem historycznym. Jest on uprzedni wobec czasu narracji i punktu widzenia narratora w jego przedstawieniu wydarzeń, stanowiących epizod z dzieciństwa. Jest on także dosłownie pojętym czasem historycznym, bo daje się zlokalizować w przestrzeni lat pięćdziesiątych i sześćdziesiątych, kiedy to były jeszcze spotykane, a nawet typowe, warunki i styl życia przeważającej części mieszkańców tak zwanej prowincji — objęte fabułą opowiadania — które stanowily pewną kontynuację uwarunkowań społecznych okresu przedwojennego. $Z$ tego też powodu krótka, narracyjna forma Himilsbacha nie jest ani wycinkowa, ani tym bardziej krótka w ujęciu świata przedstawionego Monidła; co za tym idzie, nie jest też epizodyczna czy marginalna w swej wymowie, na poziomie sensów naddanych, w sferze wyższych układów znaczeniowych. Jeśli popatrzeć na to z punktu widzenia narratologii, opowieść Himilsbacha zaczyna się rozczepiać na kilka różnych opowieści, które splatają się ze sobą na zasadzie discordii — przeciwieństwa — gdyż są motywowane różnym stanem świadomości bohaterów, dotyczącej ich uczestnictwa w wydarzeniach ${ }^{18}$. Również dlatego, że są motywowane inną perspektywą podmiotową (konceptualizacją), to jest — mówiąc kategoriami kognitywnymi — różnymi językowymi obrazami świata, a więc także c z a s e m — inaczej odczuwanym (pojmowanym) przez różnych uczestników kameralnych wydarzeń.

Jeśli przyjąć za tekst sterujący odbiorem tych kwestii Lekcje kina ${ }^{19}$ - nowe znaczenie szczegółom nadał, według irańskiego reżysera Abbasa Kiarostamiego, wykład o tym, dlaczego woda nigdy nie płynie prosto w przestrzeni naturalnej, a jabłko spadające z balkonu przebywa labiryntową drogę - to wówczas pojawi się „lekcja opowieści” Jana Himilsbacha, uwypuklą się detale i imponderabilia jego narracji. Tylko z pozoru nic one nie mówią - nic nie znaczą — a w istocie stanowią clou symboliki życia i świadomości autora, są pochodną jego filozofii i wrażliwości epickiej. Labiryntowe, szczególnie zagmatwane symbole, charakterystyczne dla człowieka Wschodu, które irański reżyser przejął z poezji perskiej, swoiście aktualizują się u Himilsbacha w przestrzeni życia (losu) szczególnie determinowanego.

Oto drobiazgi z przedakcji Monidta uruchamiające „inne” (pozafabularne) historie uczestniczące w opowiadaniu:

\footnotetext{
${ }^{18}$ Według Janusza Sławińskiego; „narratologia zasadniczo nie zajmuje się narracją, lecz formami tego, co opowiadane, szuka ona uniwersalnych kodów fabularnych" (zob. Stownik terminów literackich, red. J. Stawiński, Wrocław 1988, s. 304, cyt. za: A. Burzyńska, Anty-teoria literatury, Kraków 2006, s. 120).

${ }_{19}$ Zob. film dokumentalny: Abbas Kiarostami. Lekcja kina, reż. M. Famili, Francja 2002.
} 
Po wyjściu mamy siedziałem w domu zamknięty od środka na haczyk. Słońce leżało na łóżku rodziców, a ja przy stole $\mathrm{z}$ cieniutkich deseczek majstrowalem karmnik dla szpaków, które dopiero przyleciały do nas $z$ ciepłych krajów ${ }^{20}$.

Te proste słowa elementarnego, wybitnie rzeczowego opisu, stanowią $\mathrm{w}$ istocie świetlistą epifanię sceny życia rodzinnego z konstytuującym ją „reżyserem” — niewinnym i dobrym - dzieckiem, uosobieniem kulturowego mitu o biblijnym rodowodzie. Dorosły narrator utożsamia się z tą swoją dziecinną istotą i od niej zaczyna opowieść o niesamowitym wprost wydarzeniu, które całkowicie odwróciło tę naturalną i początkową scenę, przyniosło jej totalne zaprzeczenie, niemal zniszczenie. Dziecko niczym kreator i mag (kapłan), jakby bezwiednie i instynktownie czyni wręcz kulturowy gest - równoważny czynności oracza i siewcy — poddania się nakazowi prawa natury i ustanowienia ładu wedle prawa czasu kołowego, świętego i zarazem wegetatywnego, odradzającego życie. To prawo wiosny. Szpaki - ptaki, które dziecko wita, wspomaga je i dobrze im służy — są realnym znakiem łączącym ziemię, odległe kraje w panującym cyklu kosmicznego życia. Wymieńmy tylko ich przejmujący obraz — ludzkich dusz miotanych wieczystym wichrem w Piekle Dantego Alighieri. Dziecko, instynktownie czyniąc dobro, nawet nie wie, w czym uczestniczy, w jak wielkim i potężnym wydarzeniu — spektaklu bytu. Wie już o tym, jakby instynktownie, wierny sobie-dziecku dorosły narrator. To legitymizuje jego narracyjne kompetencje, zdolność bezpośredniego dostępu do wartości, epickiego ogarniania świata. Świetliste łóżko rodziców i stół, przy którym dziecko — czlowieczy syn — dzieli się z ptakiem, są znakami aksjologicznymi, nie tylko, więc nie wylącznie, potoczną standardową informacją i materialną konkretnością biednej izby. Aksjologiczny sens dramatu, który się tutaj wydarzy i obejmie swym zasięgiem całą rodzinę oraz wstrząśnie jej posadami, byłby nie do pojęcia bez tej epickiej miniatury, opisu-epifanii. I jeszcze słońce oraz jego ruch na scenie „pudełkowej” tej izby wyznaczać będą w bardzo istotny sposób nie tylko chronologię, ale i aksjologiczną zmianę wydarzeń, z punktu ich baśniowego charakteru, o czym opowiem w dalszej kolejności. Ruch ten będzie przez narratora zauważony w przyśpieszonym nagle ruchu swej świadomości. Tuż po tym, nagle i jakby bez fazy poprzedzającej, czytamy następny passus:

Zajęty robotą nie zauważyłem, kiedy słońce przeniosło się z lóżka koło drzwi. Zrobiło się wczesne popołudnie ${ }^{21}$.

${ }^{20}$ J. Himilsbach, Monidto, w: idem, Monidto; Przepychanka, Warszawa 1976, s. 27.

${ }^{21}$ Ibidem. 
Oświetlenie „koło drzwi” niczym teatralny reflektor wyodrębnilo scenę i próg wydarzeń, które przybrać miały nieobliczalne konsekwencje. Patrząc na to z perspektywy czasu narracji, można zauważyć zachowanie narratora, który wciela się w tym momencie swej refleksji w rozmyślanie swoje-chłopca w tamtym czasie. Niczym duch wędrujący poprzez przestrzeń i czas nawiedza on siebie-dziecko, gdzie indziej i kiedy indziej niż teraz. Sila instynktownej empatii, zdolność momentalnej metamorfozy charakteryzują narratora jako aktora i reżysera, uczestnika i scenografa wydarzeń. To cechy, które dziesiątki lat Wielkiej Reformy Teatralnej usiłowały wydobyć z wnętrza duchowego i archetypowego współczesnego człowieka. Widzenie przedmiotów, ruch „na scenie” w Monidle są niemal bliźniacze wobec koncepcji Tadeusza Kantora, nawet względem jego teorii pamięci i roli, jaką pełni w niej fotografia z ludzką twarzą (Wielopole, Wielopole).

Czas historyczny, czas kolowy, czas dobowy, to nie jedyne miary czasu w strukturze semantycznej Monidła, które wnoszą swoje autonomiczne wydarzenia, znaki i sensy, i ogniskują się wokół różnych podmiotów. Oto inny drobiazg (idźmy nadal tropem close reading) o wielkiej wartości dowodowej dla ostatecznej oceny wydarzeń oraz uczestniczących w nich osób. W porządku fabularnym może on być tylko absurdalnym epizodem, obyczajowym zgrzytem i groteskowym humorem. Tuż po przyjściu do domu ojca z wypłatą rozegrała się następująca scena:

— Kaziu, miłość mi odeszła. Już pół roku, a jak człowiekowi miłość odejdzie, to i wypić może.

Nie wiedziałem, o co tacie chodzi, chciałem tylko jednego: żeby mnie puścił. Nie mogłem znieść odoru przetrawionego alkoholu, jakim cuchną ${ }^{22}$.

To jeszcze nadal przedakcja, zatem scena ważna dla następstwa późniejszych wydarzeń. Nie jest ona obyczajową „normą” pijaka. Ojciec, w istocie poczciwina, znajduje się w stanie totalnego kryzysu, ciężkiego długotrwałego szoku i stresu. Co więcej, jest w tej chwili i w tym stanie zupełnie samotny i bezradny, skazany na nieuchronne następstwo faktów dokonanych przekwitania. Jest też tragikomiczny w tym usiłowaniu znalezienia męskiego powiernika swej tragedii. Dziecko nie może go zrozumieć. Tylko mężczyzna może w pełni pojąć, co znaczy utrata męskości - bo o nią tu chodzi — tej podstawowej cechy męskiego podmiotu. Świadomość biologicznej cezury i egzystencjalnej zmiany wpędza ojca czworga dzieci w lęk, depresję i rozpacz. Trzeba by było rozważać tutaj obarczenie winą wzorów kulturowych środowiska za nasilenie się tego stanu negatywnych przeżyć, dookolną obyczajowość, wreszcie i stan dostępnej wtedy zwykłemu człowiekowi medycyny, aby pojąć to załamanie i tę rozpacz ojca, którą narrator zapamiętał ze swego dzieciństwa, albo przeciwnie, nie pamiętał ich jako

${ }^{22}$ Ibidem, s. 28. 
dziecko, ale przypomniał je sobie jako istotne w swych dorosłych już rozmyślaniach. W tym stanie zamętu człowiek patrzy nagle na przebyte życie, ocenia je i towarzyszące mu okoliczności, przeżywa siebie bardziej jako osobę niż figurę i rolę w codziennym środowiskowym bycie. Na życie ojca padła „smuga cienia”, widmo egzystencjalnego schyłku i nagłego upokorzenia, stan niemocy. Te przeżycia oraz późniejsze czynności i decyzje ojca zogniskowane wokół „monidła”, ostateczne i desperackie usiłowania umieszczają tę kluczową postać opowiadania w zasadniczo innym ciągu zdarzeń niż przyczynowo-skutkowy łańcuch akcji. Motywują także przepaść niezrozumienia i nieporozumienia z żoną, przyczyny tragedii rodzinnej. Czas egzystencjalny, uniwersalny scenariusz bytu ludzkiego jest kluczowy w przestrzeni aksjologicznej rysującej się w Monidle. Zasadniczo to on właśnie decyduje o szerszej problematyce, właściwym temacie opowiadania oraz o humanistycznej, wyższej od „małego realizmu” wymowie utworu.

W opowiadaniu funkcjonuje jeszcze jeden czas, i to jego przestrzeń właśnie motywuje możliwość zaistnienia łącznie tych wszystkich nagle uobecnionych, a zwyczajnie osobnych opowieści (wydarzeń). Jest to czas świąteczny, czas kulturowy - c z a s karn a wa łowy. Wydarzenia wokół „monidła” nastąpily w czasie szczególnym. Powiadamiają o nim już pierwsze zdania tekstu stanowiące rodzaj prologu, a więc informujące o okolicznościach i zdarzeniach poprzedzających właściwą akcję opowiadania Himilsbacha. Prolog ten w porządku fabularnym utworu motywuje obecność i nieobecność osób w miejscu akcji, powołuje je, rzec można, na scenę pospolitego pokoju w mieszkaniu robotnika, który — co ważne — wlaśnie w tym dniu otrzymał upragnioną, a dosłownie życiodajną dla rodziny wypłatę. Oto szczególność tego czasu:

W dzień targowy zawsze było więcej ludzi w naszym mieście. Zjeżdżali się ze wszystkich stron. Handlarze bydla i koni, baby z nabiałem i drobiem, wędrowni kramarze, Cyganie i złodzieje kieszonkowi ${ }^{23}$.

W porządku semantycznym czas ten ma jednak wymiar pozaużytkowy. Jest to bowiem c zas karnawałowy, czas rytualnego i spontanicznego zarazem wydarzenia, w którym przestają działać i podlegają swoistej dysfunkcji codzienne dystanse i gradacje społeczne „dołu” i „góry”, i rozpościera się sfera nadzwyczajnych, „familiarnych" spoufaleń, zbliżeń i kontaktów ludzi z różnych środowisk, terenów i kondycji moralnych oraz materialnych. W czasie tym dokonuje się - pozostajemy nadal przy kategoriach pojęciowych Michaiła Bachtina — swoiste „wypróbowywanie” idei, sprawdzenie koncepcji bytu i wizji świata organizujących życie zbiorowe, to jest dochodzi do materializacji, jakby skondensowanego uobecnienia się, konkretyzacji tych poglądów i wartości, które determinują społeczno-ustrojowy układ zbiorowego życia

${ }^{23}$ Ibidem, s. 27. 
i wyznaczajaj jednolite miejsce i zasady bytu. Są to treści, które znacznie wykraczają poza temat obyczajowo-anegdotyczny i konstytuują temat filozoficzno-poz n a w c z y, próby wartości świata, z żyjącymi w nim bohaterami podzielonymi na lepszych i gorszych w całym układzie społecznej „góry” i „dołu”. Akcentujemy tę właśnie stratyfikację semiotyki kultury Bachtina, gdyź światopogląd i poetyka Himilsbacha tlumaczy się jaśniej w przestrzeni kultury plebejskiej. Jego „świat na opak”, jak i w ogóle fenomen pisarskiego zaistnienia, $\mathrm{z}$ całą pewnością wywodzi się z plebejskiego etosu ${ }^{24}$. Temat ten ma charakter dialogowy, przynosi dwoistą wizję świata oficjalnego i oddolnego, zmierza do konfrontacji realności i (ideowej) blagi, egzystencjalnego konkretu i ustrojowego fałszu (wmówienia). Daje ona krytyczny ogląd ludzkiego pragnienia wartości i ich odwrócenia, owej przewrotnej komercjalizacji w przestrzeni oficjalnie urządzonego świata i działania jego zreifikowanych wzorców.

Sens wydarzeń i znaczenie „monidła” odczytać można w pełni tylko poprzez e ste tykę karn awał u Michaiła Bachtina, opartą na tym plebejskim „światoodczuciu karnawałowym", dzisiaj mającą już rozległe antropologiczne rozwinięcie ${ }^{25}$. Monidto Jana Himilsbacha jest niewątpliwie przykładem estetyki uwarunkowanej karnawałem; opowiadaniem zdeterminowanym zjawiskiem wpływu praw karnawałowych na literaturę, czyli przejawem karnawalizacji .

Niedostrzeżenie w pisarstwie Jana Himilsbacha dyskursu kulturowego — wyrażającego się w historycznym przebiegu dwóch stylów kultury, oficjalnego i alternatywnego - wyłącza go z tradycji zachodnioeuropejskiego i rodzimego nurtu twórczości plebejskiej, który biegnie od teatru staroattyckiego przez Rabelais'go i Montaigne'a oraz Shakespeare'a po Becketta, jeśli powołać się tutaj wyłącznie na nazwiska symboliczne dla całego nurtu karnawalizacji literatury, i szerzej - kultury europejskiej. Estetykę karnawału, zbadaną po raz pierwszy przez Michaiła Bachtina, konstytuuje specyficzna fikcja, „nierzeczywistość”, którą powołująjej immanentne prawa i cele karnawałowego dyskursu. W Monidle tym duchem sprawczym jest swoisty prestidigitator, zawodowy

${ }^{24}$ O tym etosie traktowały studia Stanisława Grzeszczuka odnoszące się do plebejskich tradycji literatury polskiej. Pod jego kierunkiem piszący te słowa studiował literaturę staropolską i oświeceniową, i niech bodaj ta notka będzie wyrazem hołdu dla Mistrza $z$ lat studenckich i z seminarium magisterskiego.

${ }^{25}$ Fundamentalną podstawą tych badań w Polsce było wydanie krytyczne jego prac, zrazu w 1970 roku monografii Problemy poetyki Dostojeuskiego (1929, wyd. 2: 1963) oraz równie głośnej książki Tưórczość Franciszka Rabelais'go a ludowa kultura średniowiecza i renesansu (1965, tł. A. i A. Goreniowie, Kraków 1975), w końcu zaś książek Michała Bachtina: Problemy literatury i estetyki (tl. W. Grajewski, Warszawa 1982) i Estetyka twórczości słownej (tł. D. Ulicka, opr. przekł. i wst. E. Czaplejewicz, Warszawa 1986). Problemy karnawalizacji w literaturze i kulturze pojawiają się już w nurcie głównej problematyki konferencji naukowych oraz w oddzielnych wydawnictwach, np.: Teoria karnawalizacji: konteksty $i$ interpretacje, red. A. Stoff, A. Skubaczewska-Pniewska, Toruń 2000; W. Dudzik, Karnawały w kulturze, Warszawa 2005. 
oszust-domokrążca, który wie, że oferuje tandetę i kłamliwie zachwala swój produkt. W przypływie szczerości, być może w poczuciu bezkarności, uważając się za niekontrolowanego przez swego upojonego alkoholem robotniczego kontrahenta, wyznaje prawdę, zaznacza swój dystans, wręcz pogardę, do tego, co robi. Jego wynurzenia zapamiętał jednak narrator:

Nie wiadomo po co zaczął opowiadać o tym, że praca, którą wykonuje, absolutnie go nie pociaga, robi to, bo musi z czegoś żyć, jak żyje wiele ludzi, którzy po ukończeniu jakiejś szkoły artystycznej siedzą później w jakimś biurze po osiem godzin dziennie aż do końca życia, marnując swój talent i marzenia. Tak samo i on, powinien siedzieć w domu i pisać nowele i opowiadania, drukować je, a tymczasem jeździ po całej Polsce, puka do wszystkich drzwi, zbiera zamówienia ${ }^{26}$.

W tym fragmencie widać ponadto, że w uklad obyczajowo-anegdotyczny wplata się problematyka m e ta li t e r a cka, autotematyzm towarzyszący sytuacji narracyjnej dorosłego juz narratora wydarzeń z dzieciństwa. Obejmuje ona stosunek artysty do życia i ludzi, sposób pojmowania przez niego swej powinności i jego odniesienie do samego dzieła, które autor - alegorycznie upostaciowany w Monidle przez akwizytora, przedstawiciela „artystów” - zdradza z premedytacją, zamienia na komercyjny produkt, atrapę wartości. Tak rozumiany dyskurs Monidła poprzedza „świat nieprzedstawiony” Juliana Kornhausera i Adama Zagajewskiego, zawartą tam krytykę demaskującą fałsz artystyczny pisarzy unikających odpowiedzialności za prawdę o człowieku i świadomie odrywających swe dzieła od realnego świata spolecznego i równie realnego tragizmu² ${ }^{27}$. W konsekwencji tych artystycznych wyborów stylizacji i estetyzacji, kosztem prawdy oraz humanistycznego zaangażowania, dokonywała się zdrada prostego człowieka, który w stanie swego społecznego opuszczenia i osamotnienia pozostawał bezbronny wobec koryfeuszy „nowego reżimu”. Do nich to właśnie Czesław Miłosz posłał swe poetyckie memento: „Który skrzywdzileś...”. Monidło zakreśla magiczne koło wokół wydziedziczonych $z$ wartości, skrzywdzonych tak bardzo, że nawet nie potrafią sobie tego uświadomić. Podstawą tego aktu pisarskiego Himilsbacha była ludowa wrażliwość moralna, solidaryzm z pokrzywdzonymi. Ta sama wrażliwość, która wynikała z sensualnego przeżywania cierpienia i niedostatku prostaczków. Tak zaczynał swój sprzeciw wobec sztuki zamkniętej w „wieży z kości słoniowej” — romantyzm i Mickiewicz... Zawsze więc przy tego rodzaju problematyce, którą rozpoznajemy w Monidle, chodziło o rzeczy wielkiej wagi. Udział Himilsbacha we współczesnym procesie historycznoliterackim wiąże się — niczym plebejskie początki polskiego renesansu z jego nurtem

${ }^{26} \mathrm{~J}$. Himilsbach, Monidto, op. cit., s. 31.

${ }^{27}$ Zob. J. Kornhauser, A. Zagajewski, Świat nie przedstawiony, Kraków 1974. 
erudycyjnym i antykizującym - z manifestacjami „Pokolenia 1968”. Widać to w poetyce immanentnej Monidła.

Postać domokrążcy i doświadczenie „monidła” wynikają z perspektywy językowego obrazu świata dorosłego narratora, niekoniecznie zresztą przezeń sobie uświadamianej. Punkt widzenia wydarzeń i ich aksjologiczne odniesienie wynikają „instynktownie” ze świadomości opozycyjnej, alternatywnej wobec praw świata oficjalnego, w którym prostaczek został zepchnięty nie tylko poza granicę koniecznego dla życia i rozwoju statusu materialnego, ale - co więcej - poza granicę wartości przynależnych czlowiekowi. Himilsbach sięga przy tym do antyerudycyjnych wzorów kultury, do wyobraźni uksztaltowanej przez kulturę oralną, do reguł baśni. One to właśnie są wzorem dla poetyki wewnętrznej Monidła.

Można powiedzieć, że s c e na ri us z baśn i uruchamia się już na progu mieszkania, na którym zachwial się (nomen omen) ojciec wracający z wypłatą, nieco już zresztą „wstawiony”. To potknięcie się na progu według zmityzowanej świadomości ludowej jest równoznaczne z otrzymaniem „złego znaku”. Prawdziwy spektakl baśniowy rozegra się z chwilą pojawienia się nieproszonego gościa - akwizytora z Warszawy — który zaczął niewinnie od „pochwalenia Boga”, a ostatecznie przeszedł przez dom „niczym burza gradowa”. Przybysz ten, to w istocie „kusy”, podstępny diabeł kuszący ludzi i skłaniający ich do zawarcia z nim kontraktu. Jest to więc najbardziej rozpoznawalny wzór z ludowych opowieści. On sam wart jest tutaj, jako postać opowiadania, osobnej rozprawki. W utworze Himilsbacha przypadnie mu jednak znacznie większa rola - alegorycznego uosobienia fałszywej natury świata, tego wszystkiego, co przychodzi do domu i rodziny z zewnątrz. Można go konkretyzować zarówno politycznie, jak i w historycznym wymiarze cywilizacji, krzywdzącej prostych ludzi i pożerającej - niczym biblijny Lewiatan — prawdziwe wartości człowieka. Będzie to więc nie kreator, lecz prestidigitator zręcznie manipulujący uczuciami i marzeniami ludzi, po to, aby ich „kkusić”, omamić i dać zamiast wartości ich iście lucyferskie przeinaczenie, groteskowe atrapy. Śluby i pogrzeby będą w jego rękach tylko obrazkami dowolnie tasowanymi niczym karty w rękach szulera, w jakiejś pijackiej, szalonej grze. W tę dosłownie egzystencjalna grę wplącze się, jak osnowa w tkanej materii, motyw metaliteracki, problematyka centralna i symboliczna, jeśli popatrzeć na dzieje sztuki, mianowicie kwestia „gustu, czyli smaku" artystycznego i jego odniesienia do prawdy dzieła i istnienia człowieka, w jego pochodzie do - użyjmy pojęcia Herdera — człowieczeństwa. W opowiadaniu Himilsbacha chodzi o najbardziej ludzkie, pokoleniowe pragnienie przekazywania pamięci, idzie o zaistnienie w strumieniu czasu przemijania życia jednostkowego. Wraz z tym dochodzi do głosu najwrażliwszy ludzki temat prawa do godności własnej i szacunku bliźnich, niezależnie od własnej indywidualnej kondycji człowieka i miejsca zajętego przezeń w społecznym świecie.

Postać i „kostium” kusego w opowiadaniu Himilsbacha mogłyby zadowolić zapewne samego Bulhakowa, jako autora Mistrza i Matgorzaty, zły duch przypomina bowiem 
urzędnika z czasów jakiegoś „massolitu” — zredukowanej przez propagandę literatury dla mas. A oto i on sam, jak go zapamiętał narrator:

do mieszkania wszedł młody mężczyzna lat około trzydziestu, elegancko ubrany, w miękkim kapeluszu na głowie i z nową skórzaną teczką pod pachą.

Jak zdążyłem zauważyć, przybyły wykonywał pięć czynności jednocześnie: jedną ręką zamykał za sobą drzwi, drugą, przytrzymując łokciem teczkę, ściągnąl z głowy kapelusz, wycierał nogi o słomiankę, spojrzeniem lustrował ściany naszego mieszkania i mówił, ale mówił tak szybko i niezrozumiale, ze nawet po jego wyjściu nie bardzo wiedzieliśmy, o co mu chodziło $^{28}$.

Przybysz ten zdaje się być centralną osobą całego wydarzenia, stanowi spiritus movens akcji i wydaje się niepodzielnie panować nad domem i rodziną prostego czlowieka, gdzie zawitał. Celowo i pragmatycznie tworzy sytuację kontrastu i dopełnia swych czynności jako akwizytor. W porządku fabuły jest główną postacią opowiadania, reżyserem sceny obyczajowo-anegdotycznej. W przestrzeni symbolicznej utworu pelni jednak inną funkcję: pośrednika i mediatora między robotnikiem i jego rodziną a zewnętrznym i wielkim, niemal pomnikowym dla niej, światem społecznym z jego hierarchiami i systemem wzorów. Jest znakiem, wokół którego rozgrywa się nie tylko akcja zewnętrzna, lecz także ta mniej dostrzegalna i pozawerbalna, wewnętrzna, rozwijająca się w świadomości ojca pod wpływem zabiegów akwizytora dążącego do zawarcia kontraktu handlowego i wzięcia zadatku. O tej wewnętrznej przestrzeni nie decyduje bezpośrednio kusiciel-domokrążca, lecz aksjologiczne centrum, w istocie iluzja wartości — „monidło". Jest to przedmiot tyleż praktyczny i realny, co symboliczny i nadmaterialny. „Monidło” odsłoniło przed ojcem, przedmiotem zabiegów akwizytora — od zawiązania akcji po jej zakończenie i epilog (otrzymanie przez bohatera przesylki pocztowej) - swe proteuszowe oblicze. $\mathrm{Z}$ jednej strony była to ozdobna i pretensjonalna tandeta, kolorowane zdjęcie. Sprawiało ono jednak wielkie wrażenie w przestrzeni nad wyraz zgrzebnej, szarej i pozbawionej piękna, w której ludzie, nawet będąc w swym rodzinnym gnieździe pozostawali bezbarwni, nijacy, bez wyrazu i żywszych uczuć, niczym kalekie przedmioty pozbawione dystynkcji indywidualizmu. „Siła fatalna” „monidła” tkwiła w tym, że miało ono niejako obrazować (jako zdjęcie ślubne!) prestiż i godność rodziny, jej świętość wedle religijnych wyobrażeń i społecznych rytuałów, wartości, które tym prostym ludziom odebrało życie społeczne, jego reguły. $Z$ drugiej zaś strony jest to tylko środek, przedmiot pomocniczy, bo w istocie nie o samo "monidło" tutaj chodzi, lecz o to właśnie, co ono znaczy. W opowiadaniu Himilsbacha chodzi dosłow-

${ }^{28}$ J. Himilsbach, Monidto, op. cit., s. 28. 
nie o ludzką twar z, jako konieczny dla osoby ludzkiej obraz indywiduum i znak tożsamości wobec samego siebie, innych ludzi i świata, wyraz wartości podmiotowej człowieka. W świadomości kulturowej jego twarz jest znakiem i tekstem, bez których traci on swój sens. Czasem lęk przed tą utratą jest tak wielki, że twarz człowieka spowija zasłona kulturowego tabu, uniemożliwiając odsłonięcie i ujrzenie oblicza, a tym bardziej jego zbadanie czy plastyczne lub fotograficzne utrwalenie.

Prawdziwym tematem opowiadania Jana Himilsbacha nie jest „monidło”, lecz poszukiwanie ludzkiej twarzy, diabelska pokusa, by ją odzyskać, uprzytamniająca zupelnie zreifikowanemu człowiekowi jej ponadczasową wartość. W istocie zdjęć twarzy i postaci nie szuka się tylko w skromnej izbie robotniczego mieszkania, zamykanego od wewnątrz na haczyk. Są one poszukiwane w strumieniu minionego czasu, w nurcie egzystencjalnej rzeki, która niczym letejskie wody unosiła w niepamięć młode życie ojca, jego żony, a następnie dzieci. Każdy rok ich życiowego wzrostu był zarazem rokiem wydziedziczania i ogołacania $z$ wartości, pozbawiania twarzy. Tę wartość i twarz mieli zapewne inni, „godniejsi”, ci, na usługach których pozostawała kultura. Sztuka, artysta i pisarz osamotnili bohaterów Monidła i pozostawili w wiecznej szarości. Ludowe fabuly niezmiennie pokazywały plebejskich bohaterów, jak rzucają się na pańskie delicje, by choć raz spróbować tego, co się człowiekowi należy. Ojciec narratora dał się zwieść podobnemu pragnieniu. Naiwność i wypity alkohol w istocie nie determinowały chęci odzyskania siebie, twarzy swej żony i dzieci, godności i piękna, w której przecież uczestniczyli niegdyś w swej młodości. „Kusy” pokazał, ile naprawdę płaci się za makatkę z jeleniem, zawieszoną nad łóżkiem, zamiast sztuki utrwalającej prawdę o sobie, o swej ludzkiej twarzy. Opowiadanie o ludzkiej twarzy „tu i teraz”, w realiach dookolnego świata i w odniesieniu do przemijania, w tym także do historii i społecznej organizacji życia, mających swą konkretność polityczno-ustrojową, jest wielkim i poważnym tematem tragicznym. Czyż bowiem człowiek pozbawiony twarzy przez ten rzeczywisty świat jest jeszcze sobą, a więc podmiotem i miarą wartości, czy raczej tylko zredukowaną figurką, jakby bezosobową, swoiście anonimową postacią? Czyż brak wizerunku twarzy czlowieka $\mathrm{w}$ jego prywatnym i rodzinnym, także środowiskowym istnieniu nie jest konsekwencją stanu odwróconych wartości w życiu spolecznym (estetyka „świata na opak”), który zdegradowal człowieka jako osobę? To wstrząsające doznanie ojca-kontrahenta „diabła”: nagle uświadomiona w akcie deziluzji — porządku, poprawności i celowości życia - istota braku i bezpowrotnej straty — własnej twarzy w swych własnych oczach i w oczach swoich najblizszych. Świadomość zmarnowanego, jakby nikomu niepotrzebnego życia. Skazania na niepamięć. To ojciec jest prawdziwym bohaterem opowiadania Himilsbacha, to on przeżywa swój upadek i wzlot, by powrócić do swego paradoksu, niemożliwości okazania i wyartykułowania swych uczuć i tragedii, opuszczony przez artystów i przegnany z dziedziny sztuki, przeklęty i obmierzły nawet sam sobie, niezrozumiały, skazany na bełkot i nierozumne miotanie się na scenie życia. 
W porządku fabularnym, powtórzmy, ojciec jest tylko bohaterem negatywnym pijacko-awanturniczego incydentu. W porządku semantycznym, na plaszczyźnie tego, co rzeczywiście utwór komunikuje (temat) - bohater jest „ojcem zadżumionych”, przeżywa wewnętrzny wstrząs, kiedy „kusy” stawia zwierciadło przed jego twarzą, twarzami dzieci oraz żony. W lustrze tym nie było ich odbić, jakby wszyscy byli już całkiem martwi, stawszy się upiorami za życia. Zwierciadło drwiąco odbiło wykrzywione oblicza ludzi bez urody, bez znaczenia i sensu, bez godności. $Z$ tego labiryntu nie bylo już wyjścia, ojciec przemienil się ostatecznie w rozszalałego Minotaura.

Monidło dowodzi, dlaczego Himilsbach „wielkim artystą był”, dlaczego w jego opowiadaniu, w anegdocie, przy której „można boki zrywać ze śmiechu”, otwiera się czeluść tragizmu, pochłaniająca żywych ludzi — i męża, i kobietę, i dzieci. Dzieje się tak, bo artysta i pisarz opuścili ich na zawsze, posyłając w zamian diabła tandetnej komercji z koszmarnym „monidłem” - mamidłem. Realistyczne opowiadanie Himilsbacha przybrało ksztalt paraboli ze sceną ludowego moralitetu, jednego z najstarszych instrumentów dyskursu moralnego w Europie. 